\title{
Pachymeningeal Involvement with Blindness as the Presenting Manifestation of Non-Hodgkin Lymphoma
}

\section{Hodgkin Dışı Lenfomada Başlangıç Bulgusu Olarak Körlük ile Birlikte Pakimeningeal Tutulum}

\author{
(D) Charanpreet Singh ${ }^{1}$, (D) Arjun Lakshman ${ }^{1}$, (D) Aditya Jandial ${ }^{2}$, (D) Sudha Sharma ${ }^{3}$, (D) Ram Nampoothiri², (D) Gaurav Prakash ${ }^{2}$, \\ (D) Pankaj Malhotra² \\ ${ }^{1}$ Postgraduate Institute of Medical Training and Research, Department of Internal Medicine, Chandigarh, India \\ ${ }^{2}$ Postgraduate Institute of Medical Training and Research, Department of Internal Medicine, Clinical Hematology and Bone Marrow Division, \\ Chandigarh, India \\ ${ }^{3}$ Postgraduate Institute of Medical Training and Research, Department of Pathology, Chandigarh, India
}

A 44-year-old female presented with fever for 6 months and gradual-onset progressive diminution of vision in both eyes for 1 month. On examination, she had enlarged cervical, axillary, and inguinal lymph nodes; hepatomegaly $(7 \mathrm{~cm}$ under the right costal margin); splenomegaly ( $5 \mathrm{~cm}$ under the left costal margin); and bilateral renomegaly. Examination of the optic fundi (Figures $1 \mathrm{~A}$ and $1 \mathrm{~B}$ ) showed bilateral disc edema (black arrowhead) with hemorrhages in the right eye (white arrowhead). Contrastenhanced magnetic resonance imaging of the brain (Figure 2A) was done, which showed pachymeningeal enhancement (white arrow). Histopathological examination of the excised cervical lymph node showed infiltration by atypical lymphoid cells, with immunohistochemistrysuggesting diffuse large B-cell lymphoma
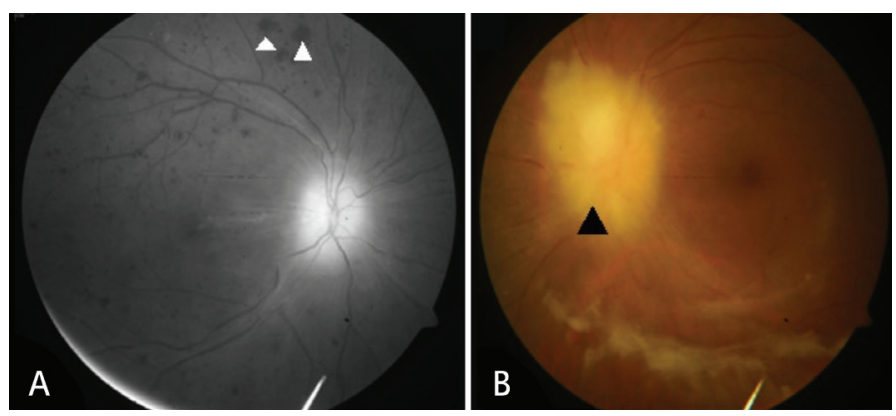

Figure 1. A) Right fundus photograph showing optic disc edema with multiple hemorrhages. B) Left fundus photograph showing large optic disc with blurred margins suggestive of papilledema.
(DLBCL)-activated B-cell-like. Microscopic examination of cerebrospinal fluid showed infiltration by malignant lymphoid cells (Figure 2B). A diagnosis of non-Hodgkin lymphoma-DLBCL with secondary central nervous system (CNS) involvement and bilateral grade 4 papilledema, likely due to pachymeningeal involvement, was made. The patient was started on systemic and intrathecal chemotherapy.

CNS involvement with aggressive lymphomas is uncommon at initial presentation and usually occurs during relapse after primary therapy [1]. Ophthalmological abnormalities are usually
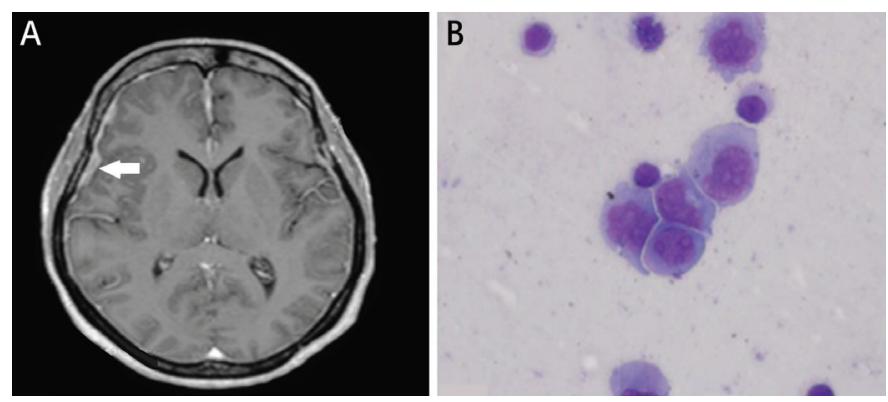

Figure 2. A) Contrast-enhanced magnetic resonance imaging of the brain showing patchy meningeal enhancement and thickening, suggestive of pachymeningitis. B) Cerebrospinal fluid cytology showing atypical lymphoid cells 2-3 times the size of normal lymphoid cells with prominent nucleoli.

๑Copyright 2018 by Turkish Society of Hematology

Turkish Journal of Hematology, Published by Galenos Publishing House

口蛋姑口 Address for Correspondence/Yazışma Adresi: Pankaj MALHOTRA, M.D.,

Postgraduate Institute of Medical Training and Research, Department of Internal Medicine,

Received/Geliş tarihi: October 12, 2016

Clinical Hematology and Bone Marrow Division, Chandigarh, India

Phone : +913862803808

E-mail : pgimerhemat@gmail.com ORCID-ID: orcid.org/0000-0003-1198-8491 
attributed to the direct invasion of the optic nerve and ocular structures by the lymphoma [2], which was not seen in our case.

Keywords: Non-Hodgkin lymphoma, Central nervous system involvement, Blindness, Papilledema

Anahtar Sözcükler: Hodgkin dışı lenfoma, Merkezi sinir sistemi tutulumu, Körlük, Papilödem

Informed Consent: It was received.
Conflict of Interest: The authors of this paper have no conflicts of interest, including specific financial interests, relationships, and/or affiliations relevant to the subject matter or materials included.

\section{References}

1. Gleissner B, Chamberlain M. Treatment of CNS dissemination in systemic Iymphoma. J Neurooncol 2007;84:107-117.

2. Güler $E$, Kutluk T, Akalan N, Akyüz C, Atahan L, Büyükpamukçu M. Acute blindness as a presenting sign in childhood non-Hodgkin lymphoma. J Pediatr Hematol Oncol 2003;25:69-72. 